\title{
Analysis and Countermeasure of the Teaching Status of "Chinese Culture Aphasia" in Japanese Majors
}

\author{
Qing Yan \\ School of Foreign Studies, Xi' an University, Xi'an, Shaanxi, China, 710065
}

Keywords: Japanese Majors, Chinese Culture Aphasia, Teaching Status, Intercultural Communication

\begin{abstract}
Language and culture are inseparable. While studying Japanese language, Japanese majors should also study Japanese and Chinese culture, master the ability of intercultural communication between China and Japan, and make their own efforts to inherit and spread Chinese culture. However, the teaching status of the Japanese majors "Chinese culture aphasia" is worrying. First of all, this paper uses a questionnaire survey method to produce a targeted questionnaire. And then investigates the mastery of Chinese culture knowledge of Japanese majors in undergraduate colleges, the ability to express Chinese culture in Japanese, and the attitude to Chinese culture aphasia in Japanese teaching. Secondly, on the basis of the survey results, the author analyzes the reasons why Japanese majors have "Chinese culture aphasia", strengthens the importance of Chinese culture education, and proposes a feasible strategy for introducing Chinese culture into Japanese majors teaching.
\end{abstract}

\section{Research Background}

Chinese culture has a long history and is profound. It has both tangible cultural heritage of material form and intangible cultural heritage of non-material form. These cultural heritages carry the values and aesthetic concepts formed by the Chinese nation in the long-term historical process. In the context of globalization, how to inherit and spread Chinese culture is a special responsibility given to every Chinese university student by the times. Japanese major students who are bridges between China and Japan are even more responsible. They should be familiar with Chinese culture and better understand the differences between Chinese and Japanese cultures while mastering the Japanese language and understanding Japanese culture. In the process of intercultural communication between China and Japan, they should reduce the communication friction caused by cultural differences and shoulder the heavy responsibility of promoting Chinese culture.

\section{A Survey of the Status Quo of Chinese Culture Learning for Japanese Majors}

\subsection{Survey Content}

The survey content of this questionnaire mainly includes two aspects. First, it investigates the Japanese majors students' mastery of Chinese cultural knowledge and their ability to express 
Chinese culture in Japanese. Secondly, it investigates Japanese majors students' attitudes towards the introduction of Chinese culture teaching in Japanese teaching.

\subsection{Survey Respondent}

The survey respondents of this questionnaire are all students enrolled in Japanese majors in sophomores and juniors in undergraduate colleges. Freshmen are in military training, and seniors are still in the internship period, so they are not included in the scope of this survey.

\subsection{Survey Tool}

The questionnaire was developed based on the Chinese Cultural English Proficiency Questionnaire used by scholars in the past, and was appropriately adjusted according to the characteristics of Japanese majors.

In order to investigate Japanese majors students' mastery of Chinese cultural knowledge and their ability to express Chinese culture in Japanese, 35 Chinese expressions representing Chinese culture were selected, and students were asked to give corresponding Japanese expressions. They include specific vocabulary such as traditional festivals, traditional literature, folk customs, traditional art, Chinese architecture, traditional costumes, Chinese medicine and history.

In order to investigate Japanese majors students' attitudes towards the introduction of Chinese culture teaching in Japanese language teaching, 23 questions were designed. These include understanding of the ability and reasons of Chinese culture to express in Japanese, interest in Chinese culture; understanding of Chinese culture and the way to express Chinese culture in Japanese, learning the meaning of Chinese culture and Japanese expression of Chinese culture, whether it is recognized for the introduction of Chinese culture teaching in Japanese teaching. Except for one multiple choice, the rest are all multiple choice questions.

The survey was conducted in mid-September and students were required to complete the questionnaire within 20 minutes. A total of 38 copies were issued, and 38 were recovered and valid.

\subsection{Analysis of Survey Results}

Through the statistics and analysis of the questionnaire, in general, the students' ability to express Chinese culture in Japanese is generally insufficient. Among the survey's proprietary vocabulary, students have a better expression in Japanese in traditional festivals, poorer expression in Japanese in traditional literature, Chinese architecture and history, and moderate expression in folk customs, traditional art and costumes, and Chinese medicine. Students generally believe that it is very difficult to complete the previous Japanese expression test, and some people think it is a little difficult. When it comes to the reasons for the difficulty of expression, it is generally believed that they have no enough vocabulary, and some people think that they have lower language ability. For the purpose of learning Japanese, many people chose the option of as a tool to pass various exams and find a good job. Some people chose the option of understanding Japanese culture. Only one person chose the option of spreading Chinese culture in Japanese and letting the world know about China. Most people have chosen the option of more interested or only interested in a few things for their interest in Chinese culture. Someone else chose the very interested option, but there are still two people who have chosen the not interested option. Most people choose the sometimes or occasional option for knowledge about whether Chinese culture is involved in Japanese language learning. For the teacher to introduce Chinese culture, most people choose the option of comparing with Japanese culture. Most people choose the option of having a certain amount of involvement or occasional appearance if they involve sufficient Chinese culture in the Japanese textbooks used. 
Most people chose the have and rarely option for teachers who have recommended Japanese language about Chinese culture during class. For the significance of learning Chinese culture and Japanese expression of Chinese culture, most people think that it is necessary to spread Chinese fine traditions when communicating with Japanese. Understanding Chinese culture plays a big role in promoting Japanese language learning, and it is necessary to train students' ability of Japanese expression of Chinese culture. Most people think that it is necessary to add Chinese culture knowledge to Japanese textbooks.

In summary, students' ability of Chinese culture Japanese expression is generally low because of the lack of the introduction of Chinese culture in the existing Japanese teaching, and there is a phenomenon of "Chinese culture aphasia". However, they still have a positive learning attitude towards excellent Chinese traditional culture, and they still have a certain awareness of actively spreading Chinese culture.

\section{Reasons for the Chinese Culture Aphasia of Japanese Majors}

The concept of "Chinese culture aphasia" was first proposed by Professor Cong Cong of Nanjing University. He pointed out that Multi-level English teaching in China only strengthens the introduction of material, institutional custom and spiritual culture content of all levels in English-speaking countries. However, the English expression of Chinese culture is basically neglected, which is the main body of communication." In fact, Japanese majors face the same problem.

The reason why Japanese majors appear "Chinese culture aphasia" can be summarized into two points on the surface. First, students have not enough Chinese cultural literacy. Second, students lack the ability to express Chinese culture in Japanese. Most students lack a large amount of accumulation for Japanese expression of Chinese culture and they do not have the ability to express these traditional cultural concepts in Japanese.

But fundamentally speaking, Japanese language teaching in Japanese majors has mainly strengthened the introduction of Japanese culture in recent years, but there is basically no introduction of Japanese expression of Chinese culture and Chinese culture. This has led to the phenomenon of "Chinese culture aphasia" for Japanese majors. They only absorb Japanese culture, but cannot spread Chinese culture, and they cannot make an effective cross-cultural communication between China and Japan. In fact, it also affects the improvement of students' intercultural communication ability between China and Japan to a certain extent.

\section{Strengthening the Importance of Chinese Cultural Education}

\subsection{It Is Conducive to Enhance Students' Recognition of Chinese Culture}

Japanese majors students will have a lot of contact to Japanese culture in the process of learning Japanese language for a long time, so they will recognize Japanese culture in a subtle way. On the other hand, the recognition of Chinese culture is declining while the recognition of Japanese culture is enhancing. The main reason is that the introduction of Chinese culture in Japanese majors teaching is not enough. Students do not understand Chinese culture and have no confidence in Chinese culture. Chinese culture is one of the oldest cultures in the world and it is the only ancient culture in the world that has not been interrupted. It is a typical representative of oriental culture and has played a major role in promoting the development of world culture. However, the outstanding achievements of Chinese culture have not received enough attention in Japanese majors teaching.

The purpose of Japanese majors teaching is to cultivate students' intercultural communication skills between China and Japan, and ultimately serve the modernization of Chinese society. If 
students have recognized the Japanese culture through systematic study and have identified barriers to Chinese culture, this is contrary to the original intention of Japanese majors teaching. Introducing Chinese culture into Japanese majors teaching and strengthening students' learning of Chinese culture can enhance students' self-confidence and recognition of Chinese culture.

\subsection{It Is Conducive to Enhance the Quality of Intercultural Communication}

The long-term neglect of the introduction of Chinese culture by Japanese majors teaching will inevitably lead to the lack of students' intercultural communication ability. Students can only passively receive the Japanese culture transmitted by the other party when they engage in intercultural communication with the Japanese, but they are unable to spread Chinese culture. Introducing Chinese culture into Japanese majors teaching can not only cultivate students' Chinese cultural literacy, but also accumulate Japanese expression of Chinese culture. It can also cultivate students' two-way and equal intercultural communication awareness and tolerance attitude when dealing with cultural differences. Therefore, students can introduce Chinese culture to Japan in fluent Japanese, which can enhance the cultural identity and help to truly improve the quality of intercultural communication between China and Japan.

\section{Strategies for Introducing Chinese Culture into Japanese Majors Teaching}

\subsection{Improve the Chinese Cultural Literacy of Japanese Majors Teachers}

Japanese majors teachers should have a solid foundation in Chinese and Japanese language, have a good understanding of Chinese and Japanese culture, and have an international perspective. Besides, teachers should guide students to learn Chinese culture and accumulate Japanese expression of Chinese culture, so that students can develop an inclusive mentality, treat Japanese and Chinese culture equally, and guide students to make unremitting efforts to inherit and spread Chinese culture.

\subsection{Add Chinese Cultural Elements into Japanese Majors Teaching Materials and Classroom Teaching}

At present, most of the textbooks and classroom teaching in Japanese majors are mainly about Japanese culture and the values of Japanese people, while Chinese culture is rarely involved. This has led to the poor ability of Japanese expression of Chinese culture for Japanese majors. The purpose of Japanese majors teaching is to cultivate students' intercultural communication competence. It is necessary to cultivate students' Japanese culture and Chinese cultural literacy at the same time. Both are equally important. Introduce Chinese cultural elements in Japanese majors textbooks and classroom teaching, and select some contrasts between Chinese and Japanese culture. Through cultural comparisons, students can accommodate cultural differences in intercultural communication, and can also increase students' accumulation of Japanese expression of Chinese culture, so that students can introduce Chinese culture to Japanese clearly and unambiguously.

\subsection{Incorporate the Examination of Chinese Cultural Literacy into Japanese Majors Teaching Evaluation System}

The current Japanese majors teaching evaluation system is mainly aimed at Japanese language and culture, and the examination of Chinese culture has not been included. In order to urge students to improve their Chinese cultural literacy and better disseminate Chinese culture, the examination of 
Chinese cultural literacy should be included in the Japanese majors teaching evaluation system. This can also improve the quality of students' intercultural communication.

\section{Conclusion}

All in all, the Japanese majors do have the phenomenon of "Chinese culture aphasia", which is related to the teaching status of the Japanese majors "Chinese culture aphasia". For Japanese majors, strengthening Chinese cultural education is crucial, which not only helps to enhance students' recognition of Chinese culture, but also helps to improve the quality of intercultural communication. Therefore, we should actively respond to the teaching status of "Chinese culture aphasia". In Japanese majors teaching, we should first improve the Chinese cultural literacy of teachers. Secondly, Chinese cultural elements should be added to teaching materials and classroom teaching. Finally, the examination of Chinese cultural literacy should be included in the evaluation system of Japanese majors teaching. In this way, students can shoulder the heavy responsibility of inheriting and promoting Chinese culture.

\section{References}

[1] Cong Cong. Chinese Culture Aphasia: The Defects of English Teaching in China [N]. Guangming Daily, 2000-10-19.

[2] Tian Su and Gao Wei. Analysis and Countermeasures of the Present Situation of Chinese Cultural Deficiency in College English Teaching [J]. Journal of Liaoning Normal University (Social Science Edition), 2011, 06: 124-130.

[3] Shao Lijun and Sun Qiuyue. Action Research on the Integration of Chinese Culture Curriculum into English Major Teaching [J]. Journal of Chinese Education, 2015, S1: 346-348.

[4] Li Qing. Exploration of Chinese Culture Teaching for English Majors in Local Undergraduate Colleges [J]. Journal of Chuxiong Normal College, 2017, 06: 134-137+145.

[5] Tan Zhaoliang. Study on Chinese Cultural Identity of English Majors-Taking English Translation Teaching of Classical Tea Poems as an Example [J]. Fujian Tea, 2018, 10: 269-270.

[6] Jia Junqin. Discussion on the Method of Two-way Importation of Chinese and Japanese Culture in Japanese Teaching_Taking "New Japanese 1" as an Example [J]. Henan Agriculture, 2017, 10: 26+28.

[7] Lei Wan. Analysis of "Chinese Cultural Aphasia" in College English Teaching from the Perspective of Global Localization [J]. English Wide Angle, 2018, 09: 54-56.

[8] Jia Weili. The Lack and Reconstruction of Chinese Culture in English Teaching in Higher Vocational Colleges-Taking Longnan Normal College as an Example [J]. Western Academic Journal, 2018, 08: 62-64. 